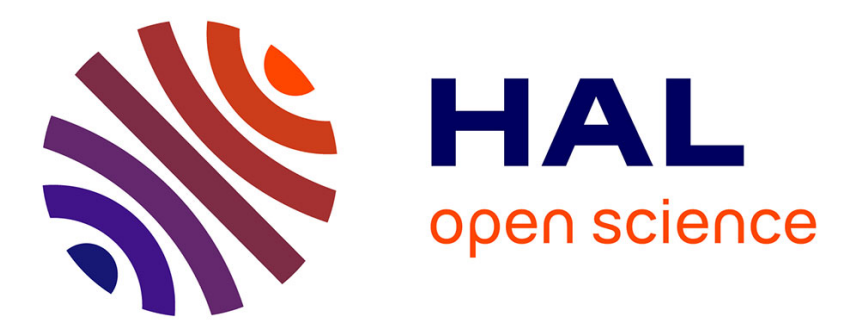

\title{
Two new and a newly recorded species of the genus Pergalumna (Acari, Oribatida, Galumnidae) from China
} Qian-Fen Zheng, Wen-Qin Liang, Guo-Ru Ren, Mao-Fa Yang

\section{To cite this version:}

Qian-Fen Zheng, Wen-Qin Liang, Guo-Ru Ren, Mao-Fa Yang. Two new and a newly recorded species of the genus Pergalumna (Acari, Oribatida, Galumnidae) from China. Acarologia, 2021, 61 (1), pp.154-172. 10.24349/acarologia/20214424 . hal-03167530

\author{
HAL Id: hal-03167530 \\ https://hal.science/hal-03167530
}

Submitted on 12 Mar 2021

HAL is a multi-disciplinary open access archive for the deposit and dissemination of scientific research documents, whether they are published or not. The documents may come from teaching and research institutions in France or abroad, or from public or private research centers.
L'archive ouverte pluridisciplinaire HAL, est destinée au dépôt et à la diffusion de documents scientifiques de niveau recherche, publiés ou non, émanant des établissements d'enseignement et de recherche français ou étrangers, des laboratoires publics ou privés.

\section{(c)(1)}

Distributed under a Creative Commons Attribution| 4.0 International License 


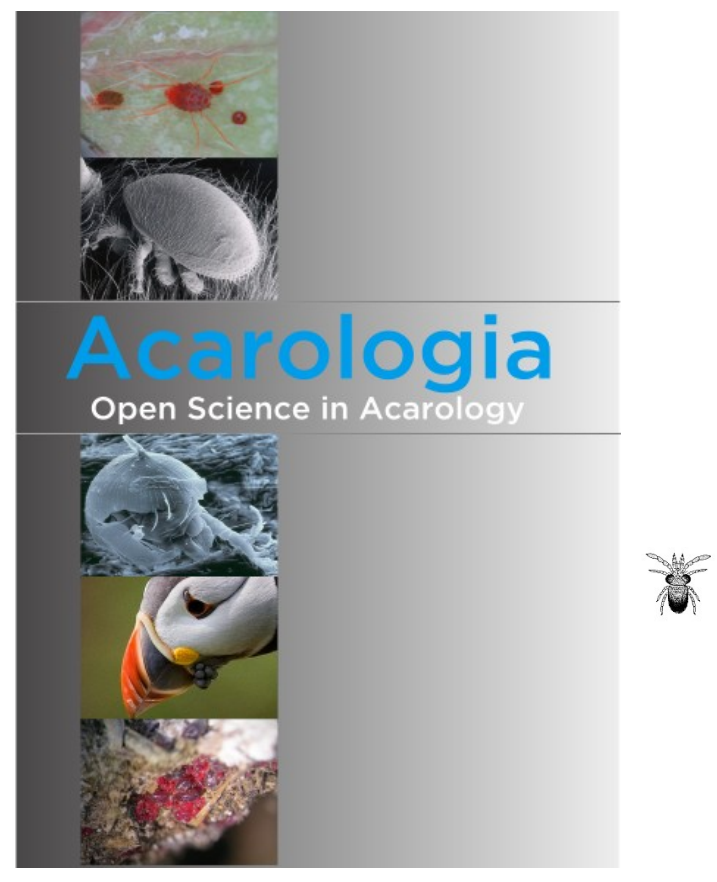

\title{
Acarologia
}

A quarterly journal of acarology, since 1959

Publishing on all aspects of the Acari

All information:

http://www1.montpellier.inra.fr/CBGP/acarologia/ acarologia-contact@supagro.fr

\section{OPEN ACCESS}

\section{Acarologia is proudly non-profit, with no page charges and free open access}

Please help us maintain this system by encouraging your institutes to subscribe to the print version of the journal and by sending us your high quality research on the Acari.

\author{
Subscriptions: Year 2021 (Volume 61): $450 €$ \\ http://www1.montpellier.inra.fr/CBGP/acarologia/subscribe.php \\ Previous volumes (2010-2020): $250 €$ / year (4 issues) \\ Acarologia, CBGP, CS 30016, 34988 MONTFERRIER-sur-LEZ Cedex, France \\ ISSN 0044-586X (print), ISSN 2107-7207 (electronic)
}

The digitalization of Acarologia papers prior to 2000 was supported by Agropolis Fondation under the reference ID 1500-024 through the «Investissements d'avenir » programme

(Labex Agro: ANR-10-LABX-0001-01)
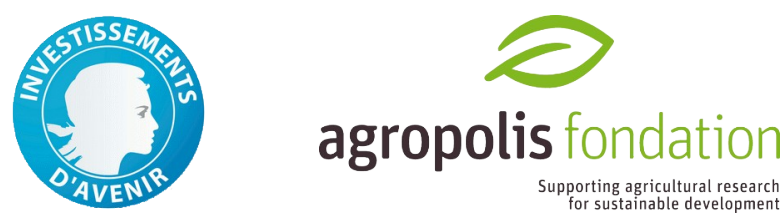

Acarologia is under free license and distributed under the terms of the

Creative Commons-BY-NC-ND which permits unrestricted non-commercial use, distribution, and reproduction in any medium, provided the original author and source are credited. 


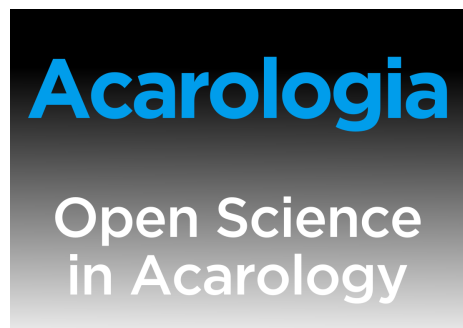

\section{Two new and a newly recorded species of the genus Pergalumna (Acari, Oribatida, Galumnidae) from China}

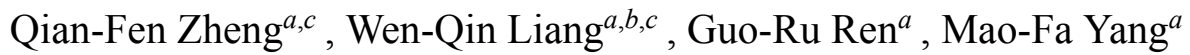 \\ ${ }^{a}$ Institute of Entomology, Guizhou University, Guizhou Provincial Key Laboratory for Agricultural Pest \\ Management of the Mountainous Region, Guiyang, 550025, China. \\ ${ }^{b}$ Guizhou Provincial Center for Disease Control and Prevention, Guiyang, 550004, China. \\ ${ }^{c}$ These authors contributed equally to this work.
}

\section{Original research}

\section{ABSTRACT}

Two new species, Pergalumna clava n. sp. and Pergalumna pilosus n. sp., and a newly recorded species, Pergalumna amamiensis Aoki, 1984 of oribatid mites are described and illustrated from China. Pergalumna clava n. sp. is different from most known species of Pergalumna in the dorsosejugal suture complete; developed four pairs notogastral porose areas, $A a$ transverse irregular wedge; short interlamellar seta and bothridial seta clavate. Pergalumna pilosus n. sp. different from most known species of Pergalumna in the dorsosejugal suture complete; $A a$ porose area transverse irregular wedge; longer interlamellar barbed; median pore and postanal porose area present.

Keywords Acari; Galumnidae; taxonomy; morphology; China

Zoobank http://zoobank.org/E7C19999-19AB-4EBO-8E8B-D92670CB2684

\section{Introduction}

Pergalumna was proposed by Grandjean, 1936 with Oribata nervosa Berlese, 1914 as type species. The genus is one of the largest genera of the family Galumnidae, which comprises two subgenera, 169 species and 14 subspecies, and collectively have a cosmopolitan distribution (Ermilov and Klimov, 2017; Subías, 2004, updated 2020). At present, 15 species and 4 subspecies of Pergalumna were recorded in China (Chen et al., 2010; Zheng et al., 2019; Subías, 2020).

During taxonomic identification of oribatid mites from China, we found two new species, Pergalumna clava n. sp. and Pergalumna pilosus n. sp. and a newly recorded species, Pergalumna amamiensis Aoki, 1984. The main goal of this study is to describe the new species, give a supplementary description to Pergalumna amamiensis and illustrate these species.

\section{Material and methods}

Samples, such as, deciduous leaves, moss, humus and grassland soil were collected by a soil-corer. Mites were extracted by using Tullgren-funnels, and then they were immersed in lactic acid and placed in DHG Series Heating and Drying Oven "DHG-9013A" at $50{ }^{\circ} \mathrm{C}$ for 8 to 72 hours, the time required varies depending on the size. Afterwards, the transparent mites were placed on a concave slide with glycerol for measurement and observation, which were made with a camera lucida using a Nikon digital microscope imaging system "NIKON NI-E+DS-RI2+NIS-AR". All body measurements are presented in micrometers. The body length was measured in lateral view, from the tip of the rostrum to the posterior edge of the 
ventral plate, to avoid discrepancies caused by different degrees of notogastral distension. Notogastral width refers to the maximum width in dorsal aspect. Lengths of body setae were measured in lateral aspect. Formulas for leg setation are given in parentheses according to the sequence trochanter-femur-genu-tibia-tarsus (famulus included). Formulas for leg solenidia are given in square brackets according to the sequence genu-tibia-tarsus.

The specimen (for scanning electron microscopy) is treated to a fully dehydrated state and dried, specimens were coated film by used rotation gold-plated-palladium alloy membrane, observed under the JEOL JCM-6000 scanning electron microscopy.

General terminology used in this paper follows that of F. Grandjean (see Travé and Vachon, 1975 for a complete list of Grandjean's references, Norton \& Behan-Pelletier, 2009 for overview, and Ermilov and Klimov, 2017 for a concise overview of the general morphology of Galumnoidea).

In the figures and text, the following abbreviations are used: rostral tooth $(r t)$; lamellar line $(L)$, sublamellar line $(S)$, prodorsal leg niche $(N)$; lateral ridges of prodorsum $(E, T)$, rostral setae (ro), lamellar setae (le), interlamellar setae (in), bothridial setae $(b s)$, dorsophragmata $(D)$, prodorsal porose area $(A d)$, notogastral porose areas $(A a, A 1, A 2, A 3)$, notogastral setae $(c$, $l a, l m, l p, h$-, $p$-series), notogastral lyrifissure (ia, im, ip, ih, ips), opisthonotal gland openings $(\mathrm{gla})$, median pore $(\mathrm{mp})$, subcapitular setae $(a, h, m)$, adoral setae $(o r)$, palp setae $(v, l, d, \mathrm{~cm}$, $a c m, u l, s u l, v t, l t)$, palp and leg solenidion $(\omega)$, cheliceral setae $(c h a, c h b)$, pedotecta I, II (Pd I, II), epimeral setae ( $a, b, c$-series), discidium (dis), adanal and anal setae (ad, an-series), genital setae $\left(g_{1}-g_{6}\right)$, aggenital setae $(a g)$, adanal lyrifissure $(\mathrm{iad})$, postanal porose $(\mathrm{Ap})$, leg trochanter, femur, genu, tibia, tarsus, respectively $(\mathrm{Tr}, \mathrm{Fe}, \mathrm{Ge}, \mathrm{Ti}, \mathrm{Ta})$, leg solenidia $(\sigma, \varphi)$, leg famulus $(\varepsilon)$, leg setae $(v, e v, b v, l, d, f t, t c, i t, p, u, a, s, p v, p l)$.

\section{Results}

\section{Galumnidae Jacot, 1925}

\section{Pergalumna Grandjean, 1936}

\section{Pergalumna clava n. sp.}

\section{Zoobank: 6A6F527D-8E3E-4BOF-A13C-6AB896B8C83F}

(Figures 1-4)

\section{Diagnosis}

Surface of notogaster smooth, prodorsum, pteromorphs outer edge and epimeral region with granules. Rostrum pointed. Lamellar and sublamellar lines present. Rostral and lamellar setae setiform, smooth. Interlamellar seta short, slightly barbed. Bothridial seta clavate, barbed head. Dorsosejugal porose areas and dorsosejugal suture present. Four pairs of notogastral porose areas developed, $A a$ transverse irregular wedge, $A 1$ rounded, $A 2$ and $A 3$ oval. Median pore area present. Postanal porose area transversely elongate oval.

\section{Description}

Measurements - Body length: 710 (holotype), 600-750 (53 paratypes); notogaster width: 540 (holotype), 450-570 (53 paratypes). No distinct differences between females and males in body size.

Integument - (Figures 1A-B, 2A-D, 4A-F). Body color brown to black. Prodorsum, pteromorphs outer edge and epimeral region with granules and striations, rest smooth.

Prodorsum - (Figures 1A, 2A, 2C, 4A-D). Rostrum pointed. Lamellar and sublamellar lines present, curving backwards at ventral end. Rostral ro (43-50) and lamellar le (78-86) setae setiform, smooth. Interlamellar seta in (23-30) short, setiform, slightly barbed. Bothridial seta bs (72-82) clavate, stalk smooth, head surface with slightly barbed and inside with particulate matter. Dorsosejugal porose area $A d(8-10 \times 20-26)$ located transversely, elongate oval.

Notogaster - (Figures 1A, 2B, 2D, 4A). Dorsosejugal suture developed, complete. Notogaster rounded posteriorly. Notogastral setae represented by 10 pairs of alveoli or 


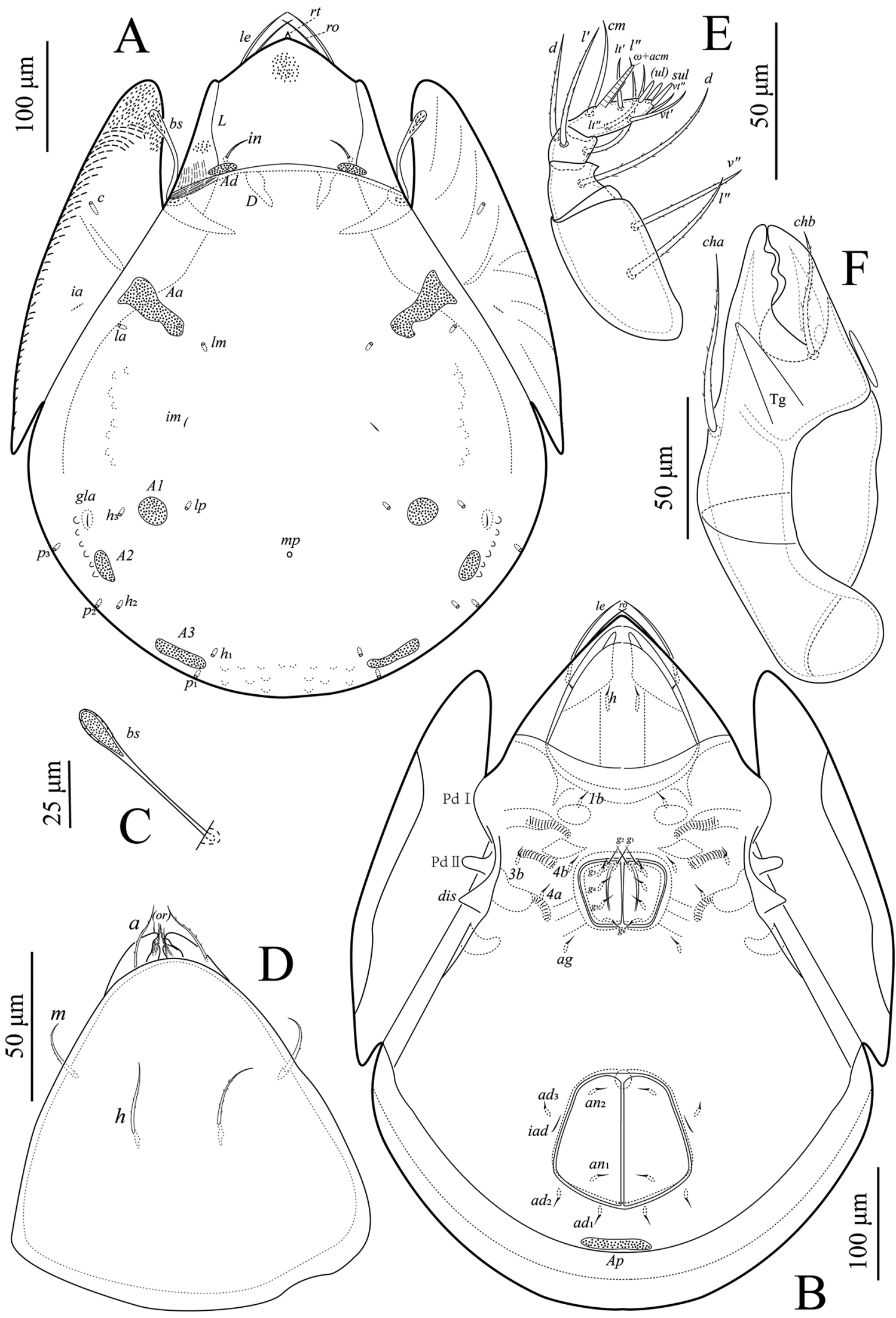

Figure 1 Pergalumna clava $\mathbf{n}$. sp., adult: A - dorsal view; B - ventral view; C - bothridial seta; D - subcapitulum, ventral view; E - palp, left, antiaxial view; F - chelicera, left, antiaxial view. 


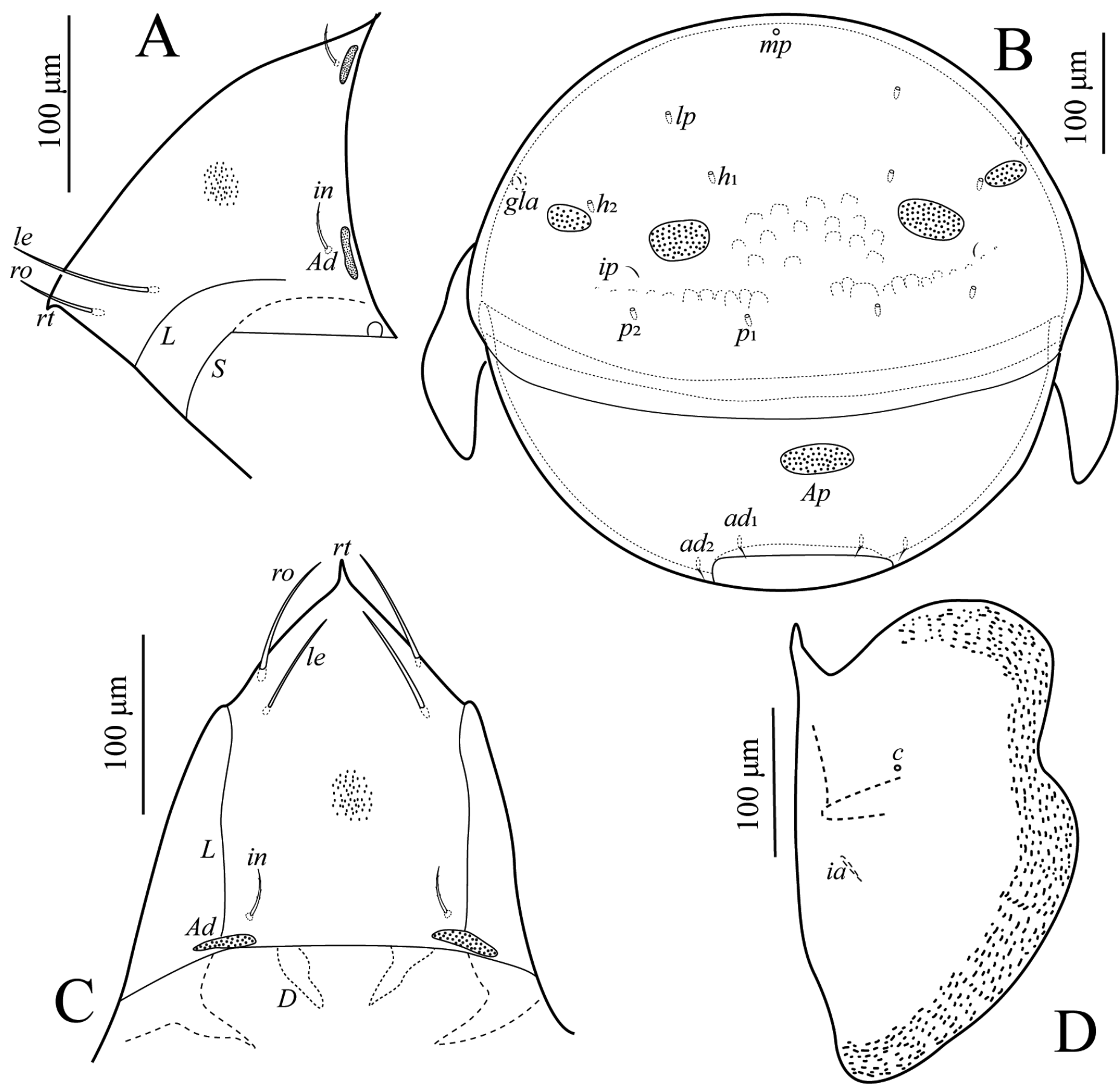

Figure 2 Pergalumna clava n. sp., adult: A - lateral view of prodorsum; B - posterior view; C - anterodorsal view of prodorsum; D pteromorpha.

microsetae. With four pairs of notogastral porose areas, $A a(16-35 \times 60-68)$ transverse irregular wedge, pointing mediad; $A 1$ (diameter 22-27) rounded; $A 2(10-14 \times 26-30)$ and $A 3$ $(8-12 \times 43-48)$ oval. Median pore present in females and males, located posterior to imaginary line connecting porose areas $A 1$. Lyrifissure $i m$ located medial to setal alveoli $l m$ and $l p$. Opisthonotal gland gla openings located lateral to $A 1$.

Gnathosoma - (Figures 1D-F, 4B). Subcapitulum size: 122-127 × 113-118, three pairs of setiform, slightly barbed, setae: $h(20-24), m(18-22)$ and $a$ (24-28). Two pairs of setiform, 
smooth adoral setae $\mathrm{or}_{1}(8-12)$ and $\mathrm{or}_{2}$ (8-12). Length of palps 105-110. Palp with setation 0-2-1-3-9 (+ solenidion $\omega)$. Length of chelicerae 160-165. Cheliceral setae cha (60-65) and chb (43-48) setiform, barbed bilaterally. Trägårdh's organ (Tg) long, elongate triangular.

Epimeral and lateral podosomal regions - (Figures 1B, 4B). Epimeral region with granules and striations. Pedotecta I and II rounded in ventral view. Discidium triangular, circumpedal carina distinct. Epimeral setal formula: 1-0-1-2. Four pairs (1a, 3b, $4 a$ and $4 b$, 5-15) of epimeral setae setiform, thin, smooth.

Anogenital region - (Figures 1B, 2B, 4B, 4D-E). Six pairs of genital setae $\left(g_{1}-g_{2}\right.$, $\left.12-22 ; g_{3}-g_{6}, 2-12\right)$, setiform, short, smooth; $g_{1}$ and $g_{2}$ parallel to each other at anterior edges of genital plate, other four pairs represented by alveoli or microsetae, arranged vertically in middle of genital plates. One pair of aggenital seta $(a g, 0-4)$ located close to genital aperture. Two pairs of anal and three pairs of adanal setae represented alveoli or microsetae. Adanal lyrifissures located close and lateral to anal plates. Adanal setae $a d_{1}$ and $a d_{2}$ located in postanal position, $a d_{3}$ anterolateral to $\mathrm{iad}$. Distance between $a d_{1}-a d_{2}$ distinctly shorter than that of $a d_{2}-a d_{3}$. Postanal porose area $A p(22-26 \times 58-62)$ elongate oval.

Legs - (Figure 3) All legs tridactylous, median claw distinctly thicker than lateral claws. Formulas of leg setation and solenidia: I (1-4-3-4-20) [1-2-2], II (1-4-3-4-15) [1-1-2], III (1-2-1-3-15) [1-1-0], IV (1-2-2-3-12) [0-1-0]. Famulus on tarsi I inserted between solenidia $\omega_{1}$ and $\omega_{2}$. Homology of setae and solenidia indicated in Table 1.

\section{Material examined}

Holotype (male), Mudanfeng National Nature Reserve ( $\left.44^{\circ} 22^{\prime} \mathrm{N}, 129^{\circ} 53^{\prime} \mathrm{E}\right)$, Mudanjiang City, Heilongjiang Province, 20 Jul. 2010, Lixia Xie and Rong Huang, in soil. 53 paratypes: 8 (5 females 3 males) same data as holotype; 7 (5 females 2 males), Liangshui National Nature Reserve $\left(47^{\circ} 9^{\prime} \mathrm{N}, 128^{\circ} 52^{\prime}\right.$ E), Yichun City, Heilongjiang Province, 25 Jul. 2010, Lixia Xie and Rong Huang, in soil; 38 (15 females 23 males), Baishilazi National Nature Reserve (4056 N, 1245ㄴ ${ }^{\prime}$ E), Dandong City, Liaoning Province, 3 Aug. 2010, Lixia Xie and Rong Huang, in soil.

\section{Type deposition}

The holotype and 7 paratypes are deposited in the Institute of Entomology, Guizhou University, Guiyang, China (GUGC) (Zhang 2018). 46 paratypes are deposited in the Guizhou Provincial Center for Disease Control and Prevention, Guiyang, China.

\section{Etymology}

The name of the new species comes from the Latin word "clava" meaning "clavate" which means that the new species bothridial seta clavate.

\section{Remarks}

In having dorsosejugal suture complete; developed four pairs notogastral porose areas, $\mathrm{Aa}$ transverse irregular wedge; short interlamellar seta and bothridial seta clavate, Pergalumna clava n. sp. is morphologically similar to Pergalumna akitaensis Aoki, 1961 and Pergalumna formicaria Berlese, 1914, redescribed by Mahunka, 1992. Differs from Pergalumna akitaensis Aoki, 1961 by the following characteristics: (1) larger porose area $A a$ and $A 3$; $A a$ and $A 3$ significantly larger than $A 1$ (versus smaller porose area $A a, A 1$ and $A 3$; and sizes not significantly different in Pergalumna akitaensis). (2) Median pore and postanal porose area present (versus median pore and postanal porose area absent). (3) Lyrifissure im located medial to $l m$ and $l p$ (versus lyrifissure $i m$ located closer to $l p$ and distanced from $l m$ ). Differs from Pergalumna formicaria Berlese, 1914, by the following characteristics: (1) Rostral and lamellar setae smooth (versus rostral and lamellar setae slightly barbed in Pergalumna formicaria), (2) Prodorsum and pteromorphs with granules (prodorsum and pteromorphs smooth). (3) Lyrifissure $i m$ located medial to $l m$ and $l p$ (versus lyrifissure $i m$ closer to $A 1$ and distanced from $A a$ ). 


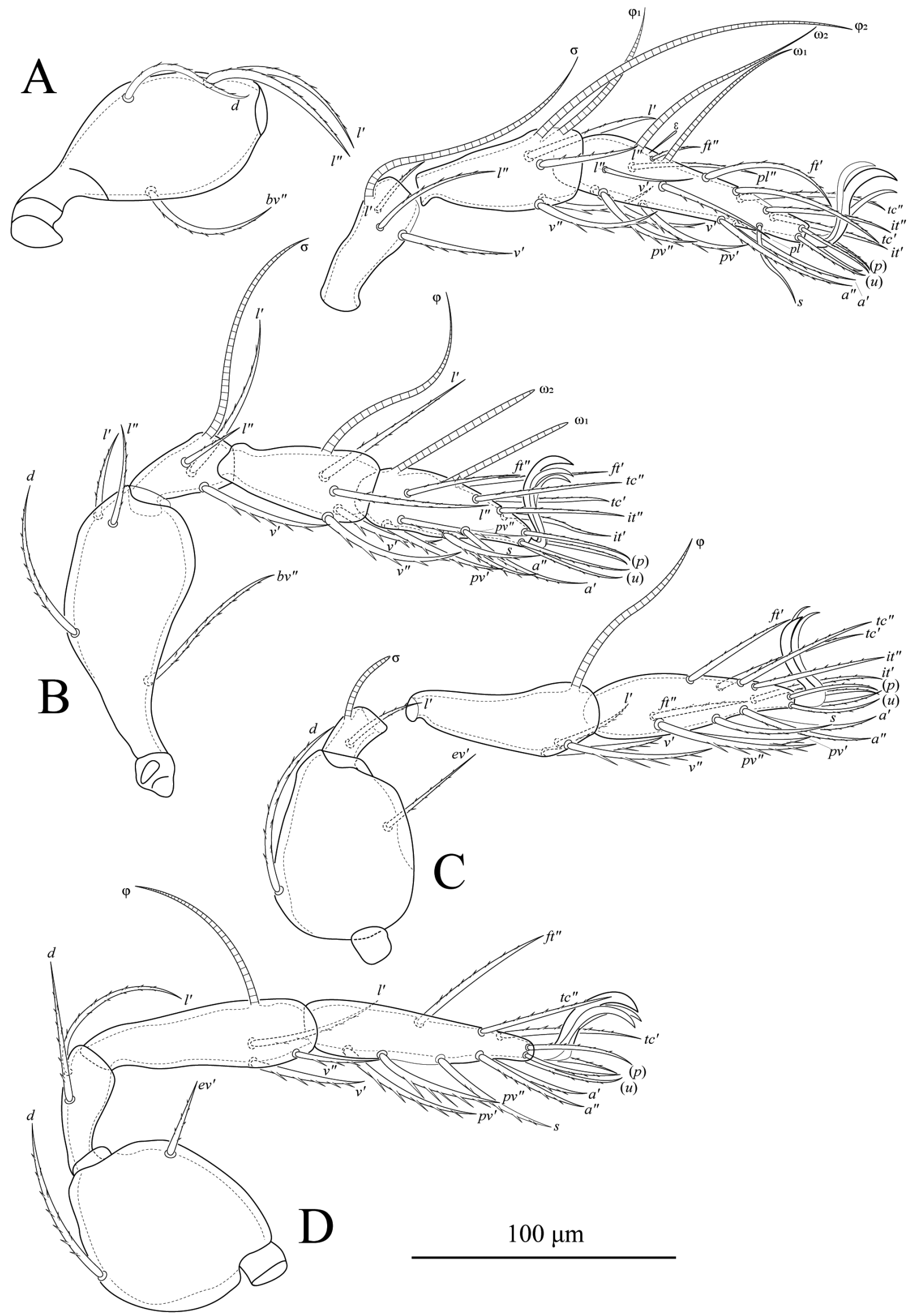

Figure 3 Pergalumna clava n. sp., adult: A - leg I, right, antiaxial view; B - leg II, right, antiaxial view; C - leg III, right, antiaxial view; D leg IV, right, antiaxial view. 


\section{Acarologia}
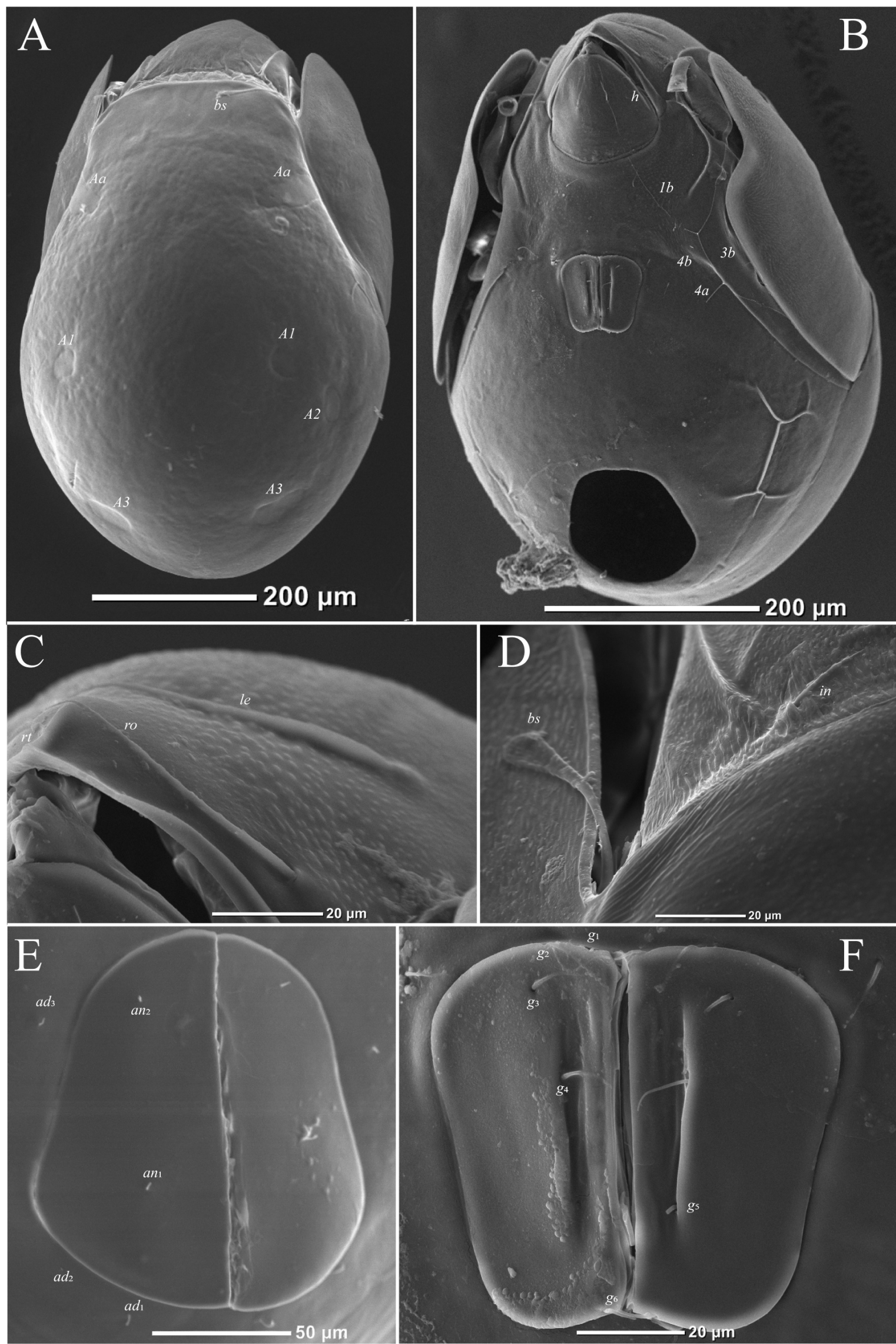

Figure 4 Pergalumna clava $\mathbf{n}$. sp., SEM micrographs of adult, macerated in lactic acid, some cero-tegument removed, some of the setae are broken. adult: A - dorsal view; B - ventral view; C - rostral and lamellar setae; D - interlamellar and bothridial setae; E - anal plates; Fgenital plates. 


\section{Pergalumna pilosus n. sp.}

Zoobank: 6E649612-AD54-4A21-8C4A-769F9A25BD46

(Figures 5-8)

Diagnosis

Body surface smooth, pteromorphs outer edge short striae, middle part of genital plates with striate. Rostrum pointed. Lamellar and sublamellar lines present. Rostral, lamellar, interlamellar and bothridial setae developed, setiform, slightly barbed. Dorsosejugal porose areas and dorsosejugal suture present. Four pairs of notogastral porose areas, $A a$ transverse long wedge, $A 1$ rounded, $A 2$ and $A 3$ oval. Median pore and postanal porose area present.

\section{Description}

Measurements - Body length: 630 (holotype), 560-670 (26 paratypes); notogaster width: 450 (holotype), 400-480 (26 paratypes). No distinct differences between females and males in body size.

Integument - (Figures 5A-B, 6A, 6C-D, 8A-E). Body color brown to black. Body surface smooth, pteromorphs outer edge short striae, the middle part of genital plates with striate, the middle of pteromorphs bilobed.

Prodorsum - (Figures 5A, 6A-B, 8A, 8F). Rostrum pointed. Lamellar and sublamellar lines parallel, curving backwards at ventral end. Rostral ro (70-80) and lamellar setae le (95-105) setiform, barbed unilaterally. Interlamellar seta in (130-140) long, setiform, first half almost smooth and the second half has a few bilaterally slightly barbed. Bothridial seta bs (120-130) setiform, slightly barbed. Dorsosejugal porose areas $A d(9-13 \times 30-33)$ located under anterior notogastral margin posterior to in, elongate oval.

Notogaster - (Figures 5A, 6A, 6C-B, 8A). Dorsosejugal suture developed, complete. Notogastral setae represented by10 pairs of alveoli. Four pairs porose areas, $A a(10-46 \times$ 100-103) located between $l a$ and $l m$, transverse long wedge; $A 1$ (diameter 25-30) rounded; $A 2$ $(10-13 \times 25-28)$ and $A 3(18-21 \times 40-43)$ oval. Median pore present in females and males, located posterior to imaginary line connecting porose areas $A 1$. Lyrifissure im located between alveoli $l m$ and $l p$. Opisthonotal gland gla openings located posterolateral to $A 1$, lateral to $h_{3}$.

Gnathosoma - (Figures 5C-E, 8D). Subcapitulum size: 161-166 $\times 153-158$, three pairs of setiform, smooth, curved subcapitular setae: $h(24-28), m(36-40)$ and $a$ (32-36). Two pairs of setiform, smooth adoral setae or $_{1}$ (5-9) and or $_{2}$ (5-9). Length of palps 140-145. Palp with setation 0-2-1-3-9 (+ solenidion $\omega)$. Length of chelicerae 192-197. Cheliceral setae cha (73-78) and chb (50-55) setiform, barbed bilaterally. Trägårdh's organ long, elongate triangular.

Epimeral and lateral podosomal regions - (Figures 5B, 6A, 8B). Epimeres smooth. Pedotecta I and II rounded in ventral view. Discidium triangular, circumpedal carina distinct. Epimeral setal formula: 1-0-1-2. Four pairs ( $1 b, 3 b, 4 a$ and $4 b$ (3-7) of epimeral setae setiform, thin, smooth.

Anogenital region - (Figures 5B, 6A, 6C, 8B, 8C, 8E). Middle part of genital plates with striate. Six pairs of genital setae $\left(g_{1}-g_{6}, 10-15\right)$, anterior edges of genital plates with two pairs of setae. One pair of aggenital seta $(a g, 4-8)$ located between genital and anal plates, closer to genital than to anal plates. Two pairs of anal and three pairs of adanal setae short, thin, smooth. Adanal lyrifissures located close and lateral to anal plates. Adanal setae $a d_{1}$ and $a d_{2}$ postanal, $a d_{3}$ located anterolateral to $\mathrm{iad}$. Distance between $a d_{1}-a d_{2}$ distinctly shorter than that of $a d_{2}-a d_{3}$. Postanal porose area oval (15-20 × 60-65).

Legs - (Figure 7). All legs tridactylous, median claw distinctly thicker than lateral claws. Formulas of leg setation and solenidia: I (1-4-3-4-20) [1-2-2], II (1-4-3-4-15) [1-1-2], III (1-2-1-3-15) [1-1-0], IV (1-2-2-3-12) [0-1-0]. Famulus on tarsi I inserted between solenidia $\omega_{1}$ and $\omega_{2}$. Solenidion on tibiae IV inserted in anterior part of the segment. Homology of setae and solenidia indicated in Table 1.

\section{Material examined}

Holotype (male), Damingshan National Nature Reserve $\left(23^{\circ} 30^{\prime} \mathrm{N}, 108^{\circ} 27^{\prime} \mathrm{E}\right)$, Nanning City, Guangxi Province, 16 May 2010, Rong Huang, in soil. 26 paratypes: 2 (1 female 1 


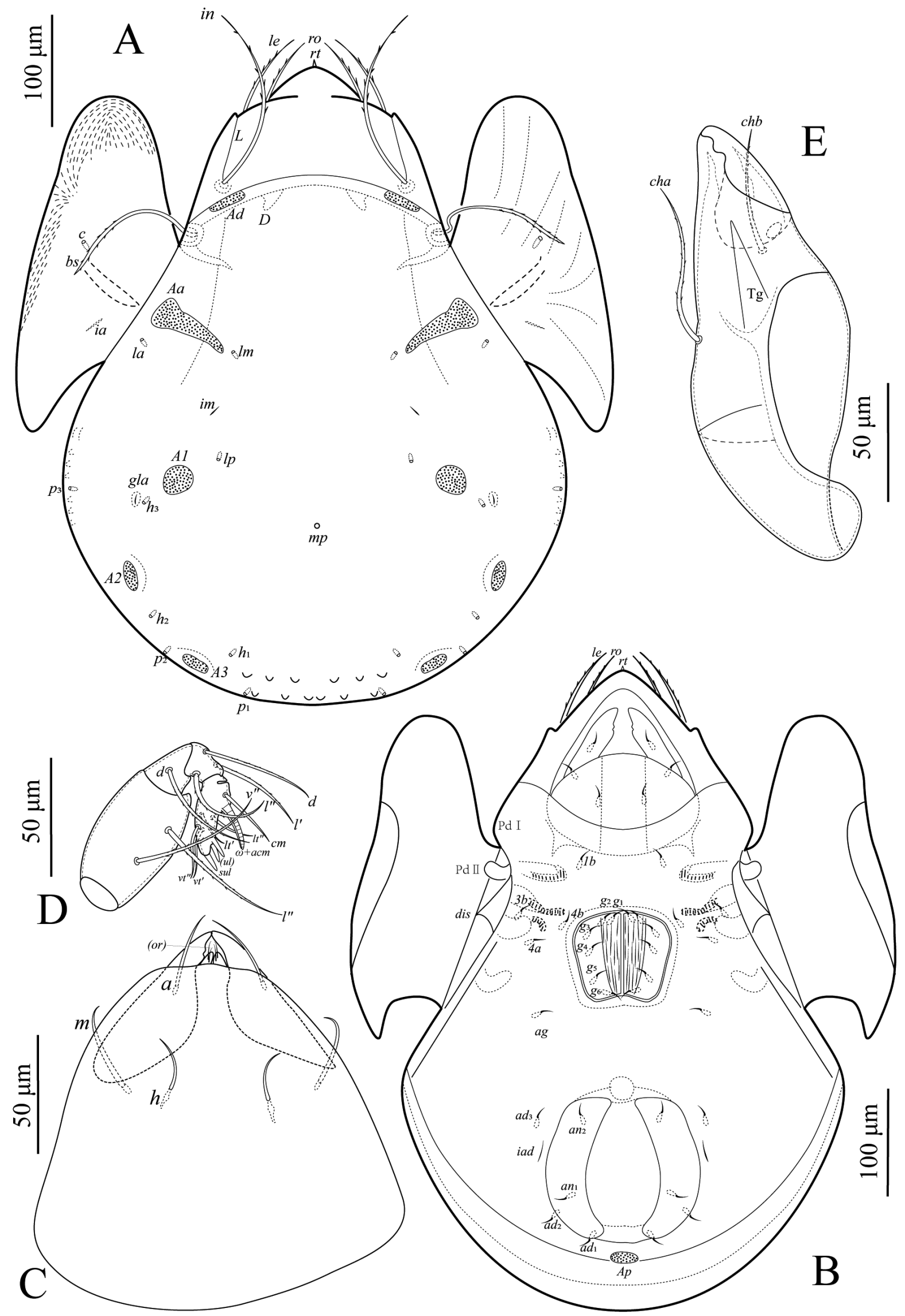

Figure 5 Pergalumna pilosus n. sp., adult: A - dorsal view; B - ventral view; C - subcapitulum, ventral view; D - palp, left, antiaxial view; E - chelicera, left, antiaxial view. 

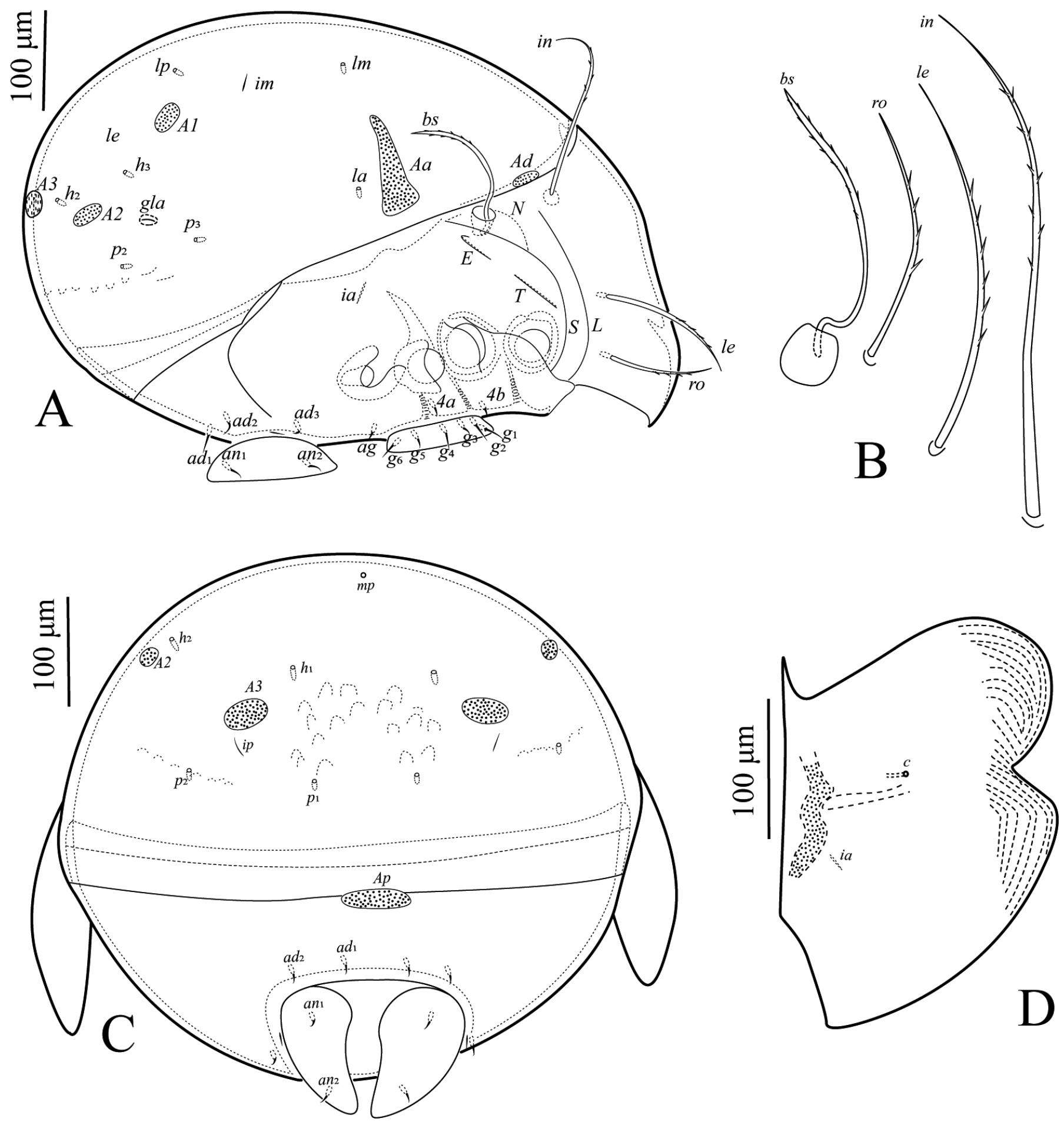

Figure 6 Pergalumna pilosus n. sp., adult: A - lateral view; B - prodorsum setae; C - posterior view; D - pteromorpha.

male) same data as holotype; 10 (3 females 7 males), Zhuque National Forest Park $\left(33^{\circ} 47^{\prime} \mathrm{N}\right.$, $108^{\circ} 35^{\prime}$ E), Xian City, Shanxi Province, 11 Jul. 2012, Wenqin Liang and Qiuxiao Tang, litter in the mixed forest; 11 ( 7 females 4 males), Wen county $\left(33^{\circ} 3^{\prime} 25^{\prime \prime} \mathrm{N}, 104^{\circ} 42^{\prime} 31^{\prime \prime} \mathrm{E}, 1800\right.$ m), Longnan City, Gansu Province, 14 Aug. 2018, Guoru Ren and Maofa Yang, in soil; 3 (2 females 1 male), Gaoleshan National Nature Reserve ( $\left.30^{\circ} 19^{\prime} 22^{\prime \prime} \mathrm{N}, 119^{\circ} 26^{\prime} 44^{\prime \prime} \mathrm{E}, 420 \mathrm{~m}\right)$, 


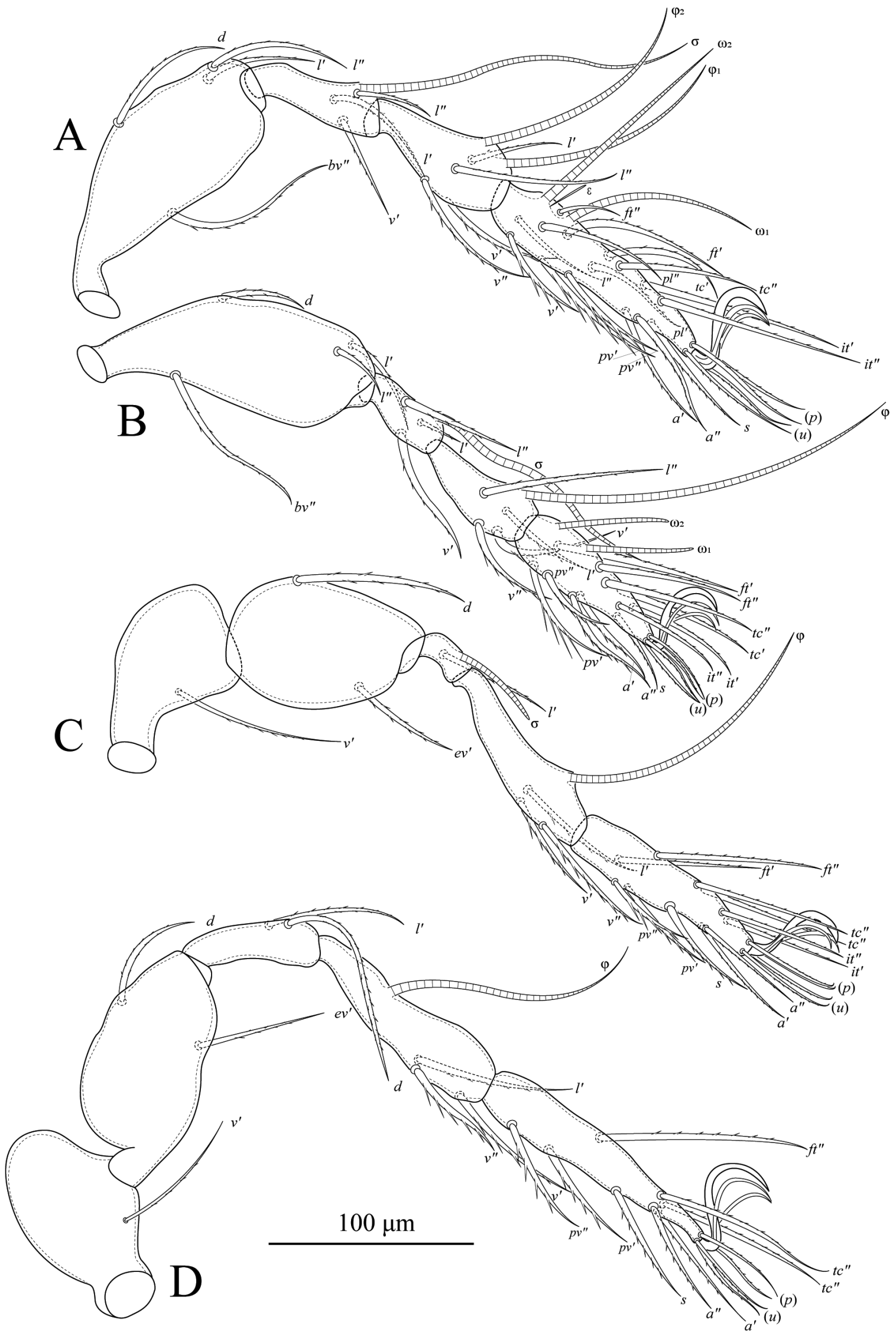

Figure 7 Pergalumna pilosus n. sp., adult: A - leg I, left, antiaxial view; B - leg II, left, antiaxial view; C - leg III, right, antiaxial view; D leg IV, right, antiaxial view. 


\section{Acarologia}
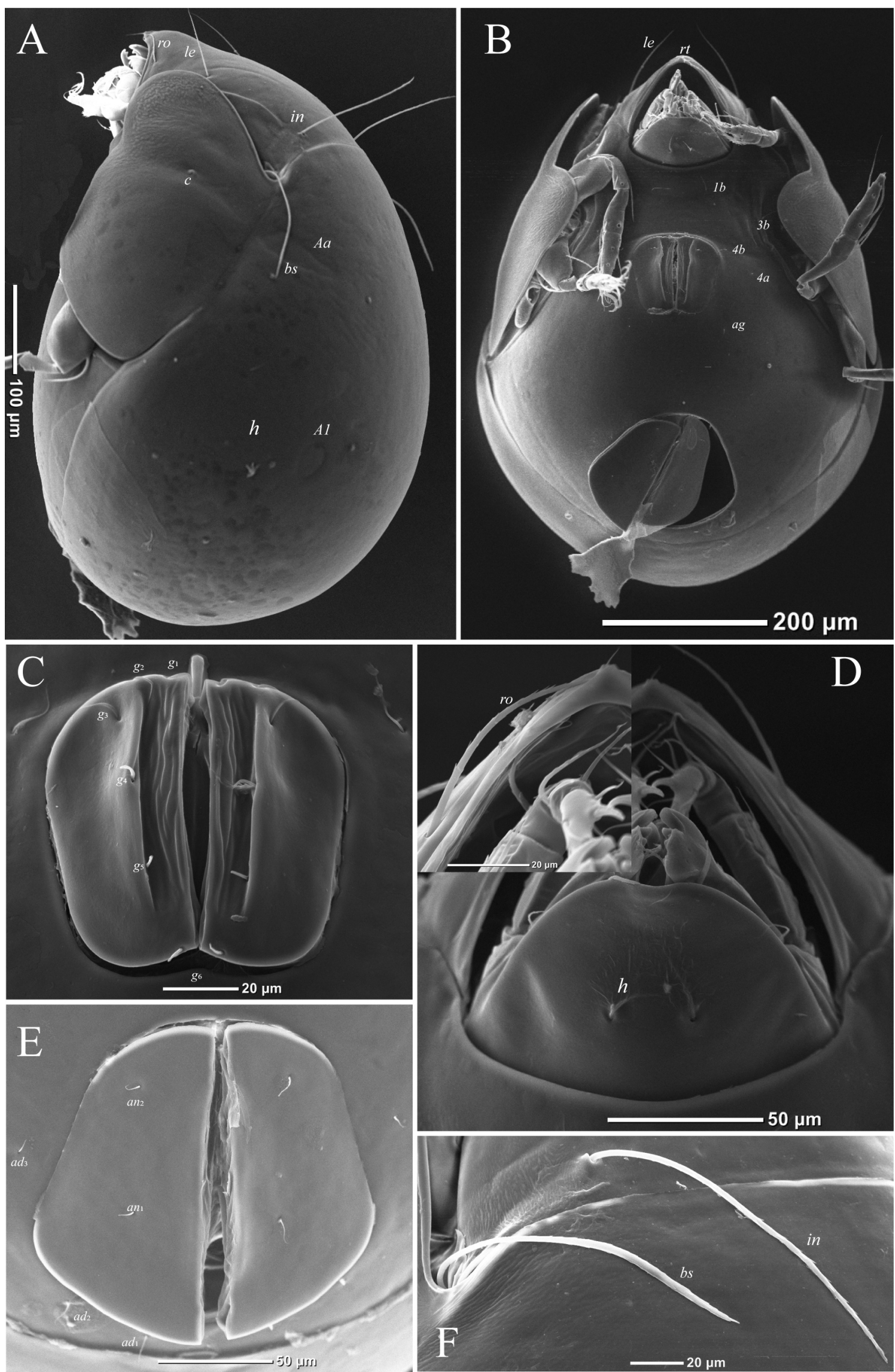

Figure 8 Pergalumna pilosus n. sp., adult: A - lateral view; B - ventral view; C - genital plates; D - subcapitulum and rostral setae; E - anal plates; F - interlamellar and bothridial setae. 
Nanyang City, Henan Province, 21 Jul. 2018, Guoru Ren and Qianfen Zheng, in soil.

\section{Type deposition}

The holotype and 16 paratypes are deposited in the Institute of Entomology, Guizhou University, Guiyang, China (GUGC). 10 paratypes are deposited in the Guizhou Provincial Center for Disease Control and Prevention, Guiyang, China.

\section{Etymology}

The name of the new species comes from the Latin name "pilosus" meaning "hairy" which refers to the comparable long cilia on rostrum, lamellar and interlamellar setae of the new species.

\section{Remarks}

In having dorsosejugal suture complete; $A a$ porose area transverse irregular wedge; longer interlamellar barbed; median pore and postanal porose area present, Pergalumna pilosus n. sp. is morphologically similar to Pergalumna variosculpturata Mahunka and Mahunka-Papp, 1999 and Pergalumna microtuberculata Bayartogtokh and Akrami, 2014, but differs from the latter two species by the following characteristics: (1) Bothridial setae setiform (versus bothridial setae lanceolate, stalk slender and head slightly incrassate and speculate in latter two species). (2) Interlamellar setae very long (130-140); significantly longer than le and ro (versus interlamellar, lamellar and rostral setae are not much difference in length). (3) Epimeral region smooth (versus epimeral region with granules and striations).

\section{Pergalumna amamiensis Aoki, 1984}

(Figures 9-12)

\section{Supplementary description}

Measurements - Body length: 540-680; notogaster width: 390-490. No distinct differences between females and males in body size.

Integument - (Figures 9A-B, 10A, 10C-D, 12A-F). Body color brown to black. Body surface foveolate. Prodorsum, genital plates, epimeral and lateral podosomal regions large granules; pteromorphs outer edge and anal plates and the surrounding with granules.

Prodorsum - (Figures 9A, 10A-B, 12A, 12C-D). Rostrum pointed. Lamellar and sublamellar lines parallel, long, curving backwards at ventral end. Rostral ro (75-85) and lamellar setae le (100-110) setiform, barbed unilaterally. Interlamellar seta in (140-150) long, setiform, slightly barbed. Bothridial seta $b s$ (120-130) lanceolate, stalk slender, head slightly incrassate and spiculate. Dorsosejugal porose areas $(8-12 \times 24-28)$ located under anterior notogastral margin posterior to in, elongate oval.

Notogaster - (Figures 9A, 10A, 10C-D, 12A, 12D). Dorsosejugal suture developed, complete. Notogastral setae represented by10 pairs of alveoli. Four pairs porose areas, $A a$ (10-35 $\times 50-60)$ located above to $l a$, transverse long wedge; $A 1$ (diameter 23-28) rounded; $A 2$ (17-22 × 25-28) oval; $A 3$ (diameter 23-28) rounded from posterior view. Median pore present in females and males, located middle to $A 2$. Lyrifissure $i m$ located between alveoli $l m$ and $l p$, closer to $l p$ than $l m$. Opisthonotal gland gla openings located lateral to $A 1$.

Gnathosoma - (Figures 9C-E, 12B). Subcapitulum size: 160-165 $\times 120-125$, three pairs of setiform, smooth, curved subcapitular setae: $h(18-22), m(28-32)$ and $a(36-40)$. Two pairs of setiform, smooth adoral setae $o r_{1}$ (11-13) and $o r_{2}$ (11-13). Length of palps 120-130. Palp with setation 0-2-1-3-9 (+ solenidion $\omega)$. Length of chelicerae 190-200. Cheliceral setae cha (60-65) and chb (55-60) setiform, barbed bilaterally. Trägårdh's organ long, elongate triangular.

Epimeral and lateral podosomal regions - (Figures 9B, 10B, 12B). Epimeres strong granules. Pedotecta I and II rounded in ventral view. Discidium triangular, circumpedal carina distinct. Epimeral setal formula: 1-0-1-2. Four pairs of epimeral setae setiform, thin, smooth $1 b$ (20-25), 3b (25-30), $4 a(20-25)$ and $4 b(20-25)$.

Anogenital region - (Figures 9B, 10A, 10C, 12B, 12E-F). Middle part of genital plates with striate. Six pairs of genital setae $\left(g_{1}-g_{2}, 25-30 ; g_{3}-g_{6}, 15-20\right)$, anterior edges of genital 


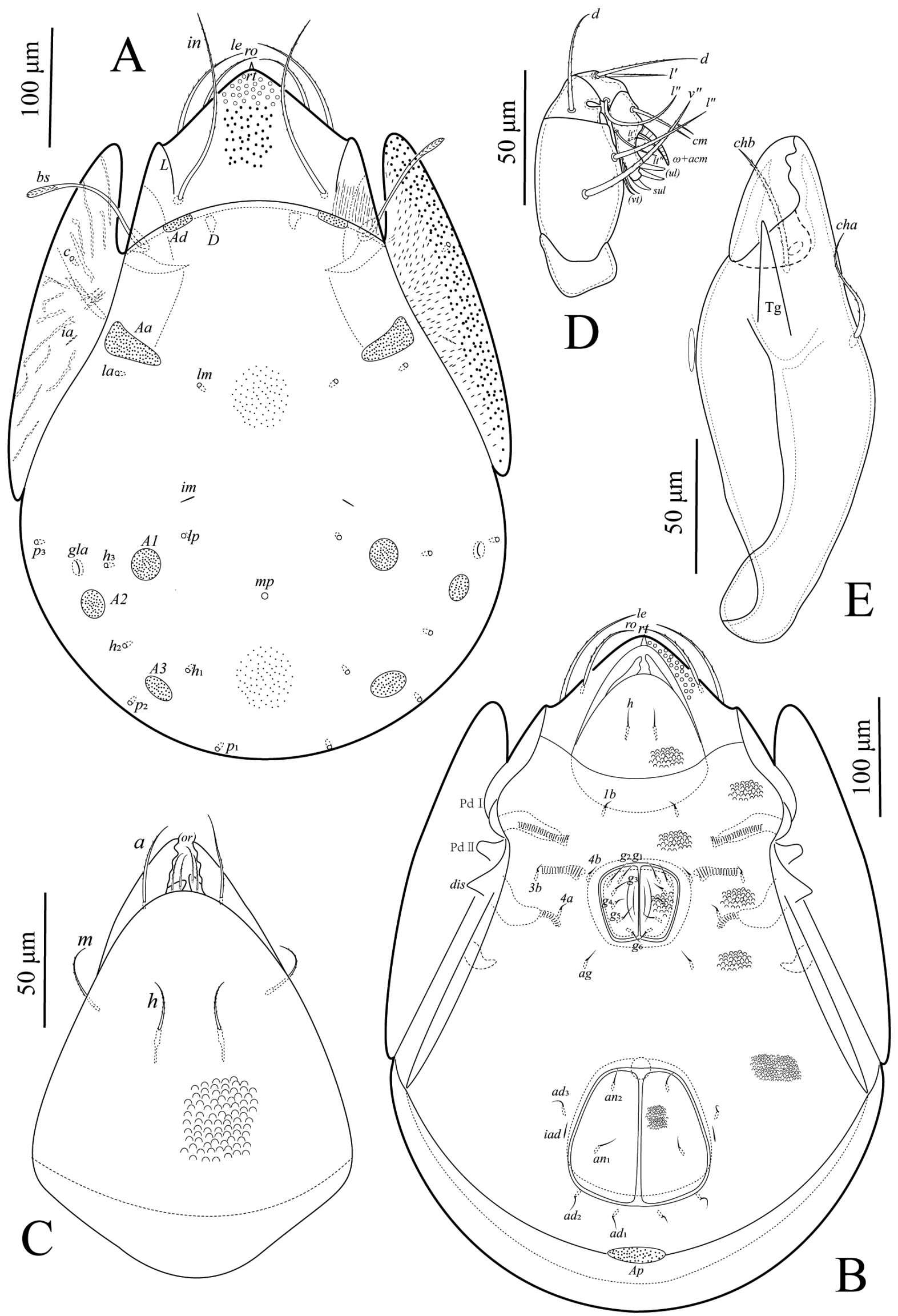

Figure 9 Pergalumna amamiensis Aoki, 1984, adult: A - dorsal view; B - ventral view; C - subcapitulum, ventral view; D - palp, left, antiaxial view; $\mathrm{E}$ - chelicera, right, antiaxial view. 

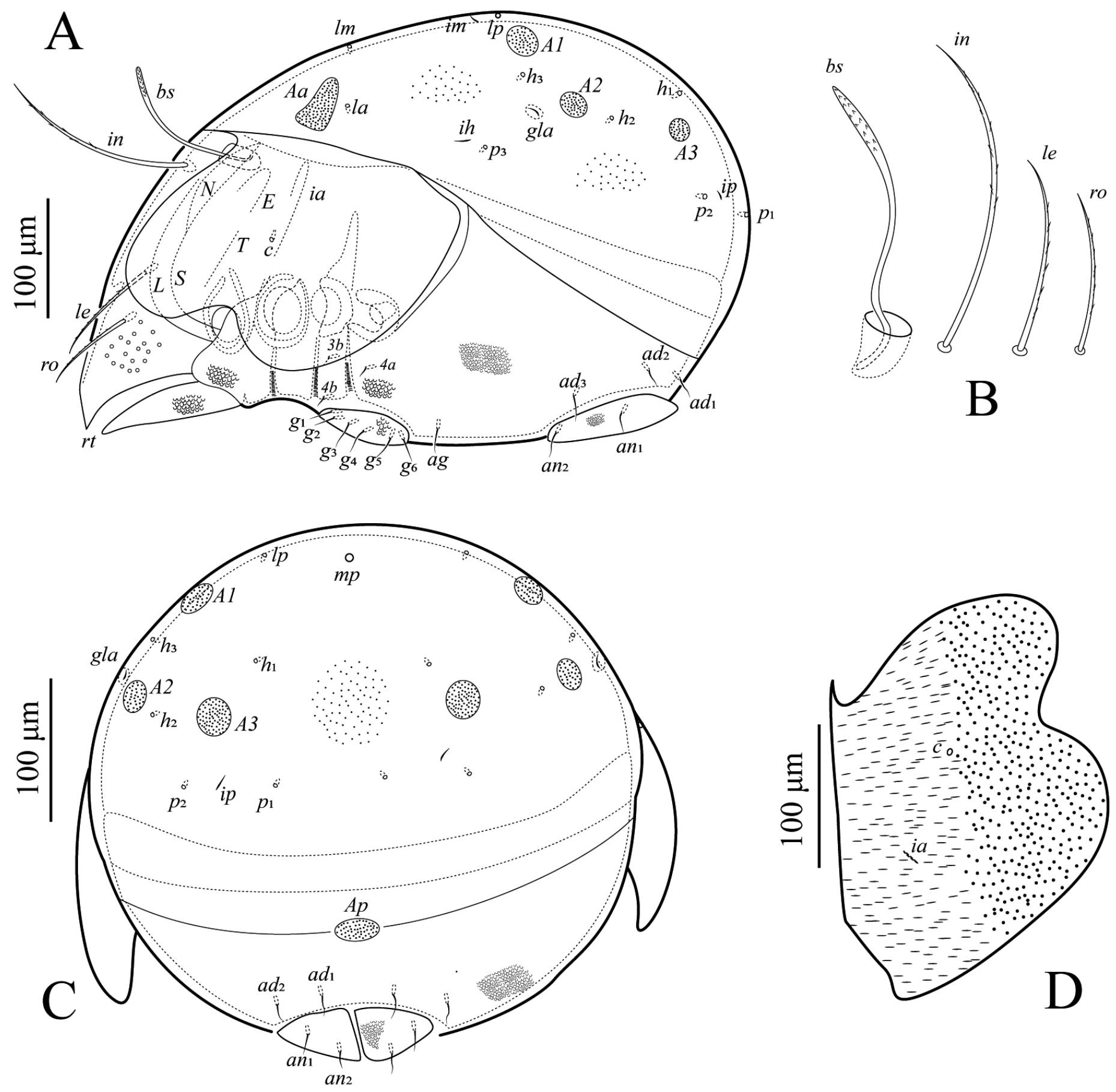

Figure 10 Pergalumna amamiensis Aoki, 1984, adult: A - lateral view; B - prodorsum setae; C - posterior view; D - pteromorpha.

plates with two pairs of setae. One pair of aggenital setae $(\mathrm{ag}, 10-15)$ located between genital and anal plates, closer to genital than to anal plates. Two pairs of anal $\left(a n_{1}-a n_{2}, 10-15\right)$ and three pairs of adanal setae $\left(a d_{1}-a d_{3}, 10-20\right)$, all short, thin, smooth. Adanal lyrifissures located close and lateral to anal plates. Adanal setae $a d_{1}$ and $a d_{2}$ postanal, $a d_{3}$ located anterolateral to iad. Distance $a d_{1}-a d_{2}$ distinctly shorter than $a d_{2}-a d_{3}$. Postanal porose area oval (13-18 $\times$ 28-33).

Legs - (Figure 11). All legs tridactylous, median claw distinctly thicker than lateral 


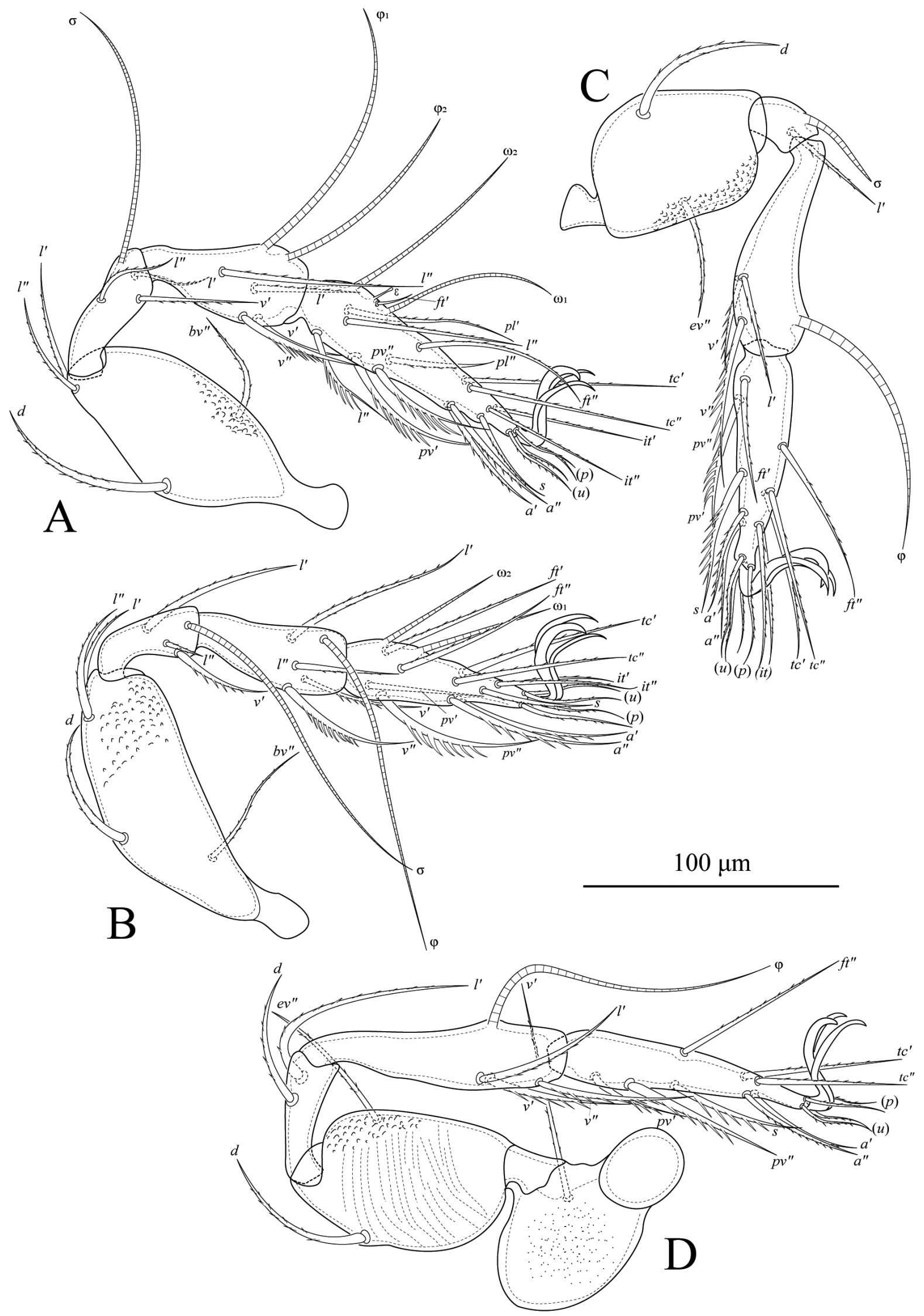

Figure 11 Pergalumna amamiensis Aoki, 1984, adult: A - leg I, right, antiaxial view; B - leg II, right, antiaxial view; C - leg III, left, antiaxial view; D - leg IV, left, antiaxial view. 


\section{Acarologia}
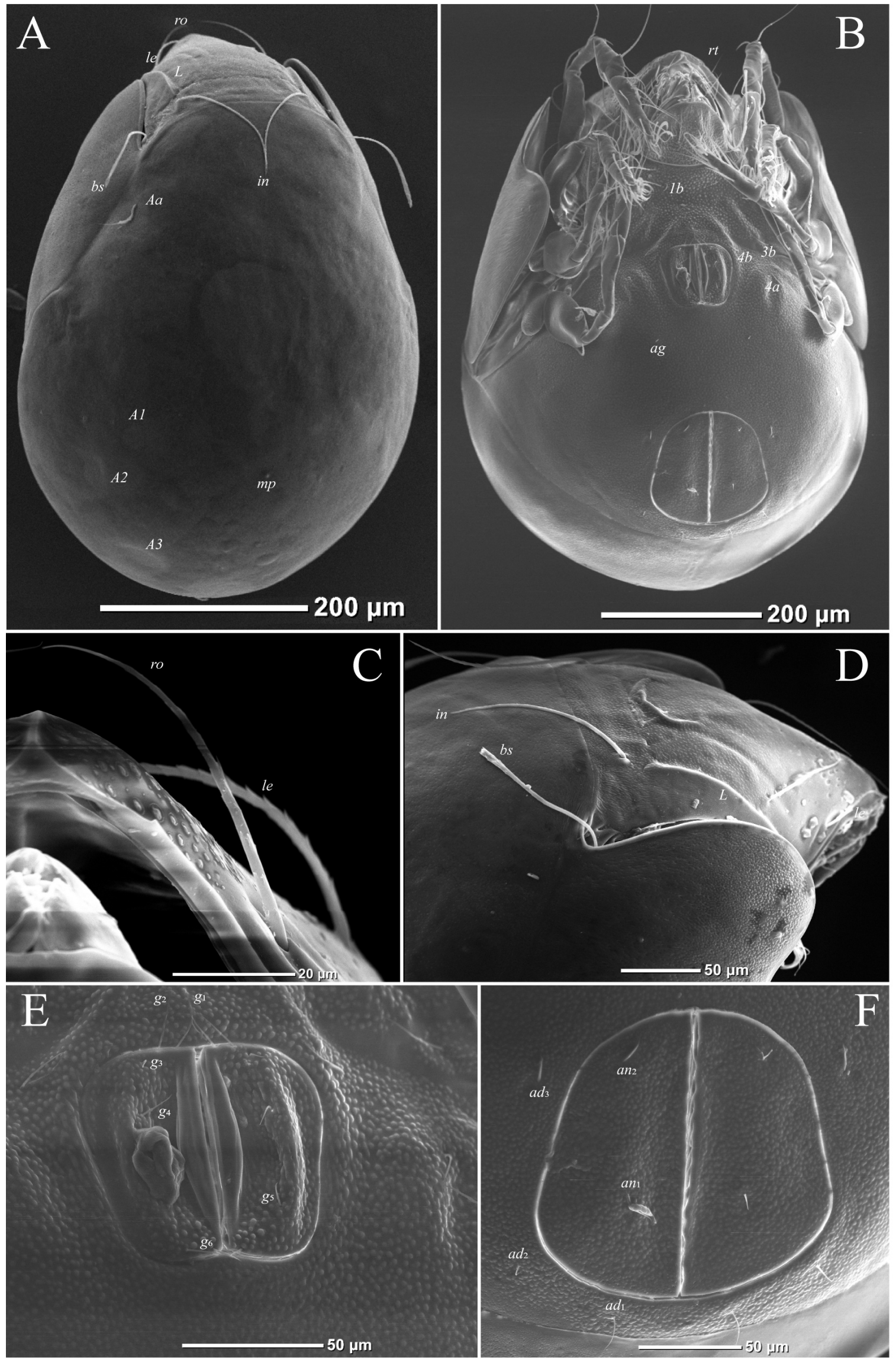

Figure 12 Pergalumna amamiensis Aoki, 1984, adult: A - dorsal view; B - ventral view; C - rostral and lamellar setae; D - detail of prodorsum in lateral view; E - genital plates; F - anal plates. 
Table 1 Leg setation and solenidia of adult Pergalumna clava $\mathbf{n}$. sp., Pergalumna pilosus n. sp. and Pergalumna amamiensis Aoki, 1984.

\begin{tabular}{llllll}
\hline Leg & $\mathrm{Tr}$ & $\mathrm{Fe}$ & $\mathrm{Ge}$ & $\mathrm{Ti}$ & $\mathrm{Ta}$ \\
\hline $\mathrm{I}$ & $v^{\prime}$ & $d,(l), b v^{\prime \prime}$ & $(l), v^{\prime}, \sigma$ & $(l),(v), \varphi_{1}, \varphi_{2}$ & $(f t),(t c),(i t),(p),(u),(a), s,(p v), v^{\prime},(p l), l^{\prime \prime}, \varepsilon, \omega_{1}, \omega_{2}$ \\
II & $v^{\prime}$ & $d,(l), b v^{\prime \prime}$ & $(l), v^{\prime}, \sigma$ & $(l),(v), \varphi$ & $(f t),(t c),(i t),(p),(u),(a), s,(p v), \omega_{1}, \omega_{2}$ \\
III & $v^{\prime}$ & $d, e v^{\prime}$ & $l^{\prime}, \sigma$ & $l^{\prime},(v), \varphi$ & $(f t),(t c),(i t),(p),(u),(a), s,(p v)$ \\
IV & $v^{\prime}$ & $d, e v^{\prime}$ & $d, l^{\prime}$ & $l^{\prime},(v), \varphi$ & $f t^{\prime \prime},(t c),(p),(u),(a), s,(p v)$ \\
\hline
\end{tabular}

Note: Roman letters refer to normal setae, Greek letters to solenidia (except $\varepsilon$ = famulus). Single prime (') marks setae on the anterior and double prime (") setae on the posterior side of a given leg segment. Parentheses refer to a pair of setae. $\mathrm{Tr}-$ trochanter, $\mathrm{Fe}-\mathrm{femur}$, $\mathrm{Ge}-$ genu, Ti - Tibia, $\mathrm{Ta}$ - tarsus.

claws. Formulas of leg setation and solenidia: I (1-4-3-4-20) [1-2-2], II (1-4-3-4-15) [1-1-2], III (1-2-1-3-15) [1-1-0], IV (1-2-2-3-12) [0-1-0]. Famulus on tarsi I inserted between solenidia $\omega_{1}$ and $\omega_{2}$. Solenidion on tibiae IV inserted in anterior part of the segment. Homology of setae and solenidia indicated in Table 1.

\section{Material examined}

15 females 11 males, Tianmushan National Nature Reserve $\left(30^{\circ} 20^{\prime} 4^{\prime \prime} \mathrm{N}, 119^{\circ} 26^{\prime} 18^{\prime \prime} \mathrm{E}\right.$, 810 m), Hangzhou City, Zhejiang Province, 27 Jul. 2018, Guoru Ren and Qianfen Zheng, in moss. 2 females 1 male, Gujingyuan National Nature Reserve $\left(31^{\circ} 3^{\prime} 7^{\prime \prime} \mathrm{N}, 116^{\circ} 30^{\prime} 7^{\prime \prime}\right.$ E, 450 m), Haozhou City, Anhui Province, 25 Jul. 2018, Guoru Ren and Qianfen Zheng, in deciduous leaves.

\section{Specimen deposition}

26 samples are deposited in the Institute of Entomology, Guizhou University, Guiyang, China (GUGC). 3 specimens are deposited in the Guizhou Provincial Center for Disease Control and Prevention, Guiyang, China.

\section{Remarks}

This species was originally described by Aoki (1984) from Japan, but the original description was brief and not completely illustrated, so we gove a supplementary description and illustrations. Apart from the lacking characteristics, the Chinese specimens differ from the Japanese specimens by the rostral, lamellar, interlamellar and bothridial setae which are slightly barbed. Hence, based on these supplementary data, the main characters of P. amamiensis are: body size: $540-680 \times 390-490$, body surface densely foveolate granules; rostrum pointed; lamellar and sublamellar lines present; rostral, lamellar and interlamellar setae developed, setiform, slightly barbed; bothridial setae spindle-shaped, stalk slender and head slightly incrassate and spiculate; dorsosejugal porose areas and dorsosejugal suture present; four pairs of notogastral porose areas, $A a$ transversely wedge-shaped, $A 1$ rounded, $A 2$ and $A 3$ oval; median pore and postanal porose area present; epimeral setal formula 1-0-1-2; ventral setae, genital setae, epimeral setae, anogenital and adanal setae represented by microsetae; all legs tridactylous, leg setae not modified.

\section{Acknowledgements}

We would like to express our gratitude to Professor Roy A. Norton (State University of New York, Syracuse, U. S. A.) for providing literature. Thanks also due to Lixia Xie, Rong Huang and Qiuxiao Tang (Institute of Entomology, Guizhou University, Guiyang of China) for provided samples. This project was supported by the Program of Ministry of Science and Technology of the People's Republic of China (2015FY210300); independent research topic of national key laboratory for the prevention and control of infectious diseases (No. 2018SKLID305); the Program of Excellent Innovation Talents, Guizhou Province, China (No. 20164022); 
the Program of Science and Technology of Guizhou Province (No. Qian Ke He Platform talent [2018]5767); special funds of research team for experimental diagnostic technique and molecular epidemiological study of major infectious disease in Guizhou Province (Program of scientific and technological innovation team of Guizhou Province, No. Qian Ke He Platform talent [2018]5606); Science and Technology Fund project of Guizhou Provincial Health and Family Planning Commission (No. gzwjkj2018-1-066).

\section{References}

Aoki J. 1961. On six new oribatid mites from Japans. Jpn. J. Sanit. Zool., 12(4): 233-238 doi:10.7601/mez.12.233

Aoki J. 1984. New and unrecorded oribatid mites from Amami-Ohshima Island, Southwest Japan. Zool. Sci., 1: 132-147.

Bayartogtokh B., Akrami M.A. 2014. The soil mite family Galumnidae of Iran (Acari: Oribatida). J. Nat. Hist., 48(15-16): 881-917. doi:10.1080/00222933.2013.840397

Berlese A. 1914. Acari nuovi. Manipulus IX. Redia, 10(1): 113-150.

Chen J., Liu D., Wang H.F. 2010. Oribatid mites of China: a review of progress, with a checklist. Zoosymposia, 4: 186-224. doi:10.11646/zoosymposia.4.1.14

Ermilov S.G., Klimov P.B. 2017. Generic revision of the large-winged mite superfamily Galumnoidea (Acari, Oribatida) of the world. Zootaxa, 4357(1): 1-72. doi:10.11646/zootaxa.4357.1.1

Ermilov S.G., Starý J. 2017. Two new species of the genus Pergalumna (Acari, Oribatida, Galumnidae) from Northern Vietnam. Syst. Appl. Acarol., 22(4): 494-508. doi:10.11158/saa.22.4.6

Grandjean F. 1936. Les Oribates de Jean Frédéric Hermann et de son père. Ann Soc Entomol Fr, 105: $27-110$.

Jacot A.P. 1925. Phylogenie in the Oribatoidea. Am. Nat., 59(662): 272-279. doi:10.1086/280038

Mahunka S. 1992. "Pelops" and "Oribates" species in the berlese-collection (Acari). Acta Zool. Acad. Sci. Hung., 38(3-4): 213-260.

Mahunka S., Mahunka-Papp L. 1999. Oribatids (Acari: Oribatida) from the Aggtelek National Park (NE Hungary). The Fauna of the Aggtelek National Park. Budapest: Hungarian Natural History Museum. p. 619-651.

Norton R.A., Behan-Pelletier V.M. 2009. Suborder Oribatida. Chapter 15. In: Krantz G.W., Walter D.E (Eds). A Manual of Acarology. Lubbock: Texas Tech University Press. p. 430-564.

Subías L.S. 2020. Listado sistemático, sinonímico y biogeográfico de los Ácaros Oribátidos (Acariformes: Oribatida) del mundo (excepto fósiles), $15^{\mathrm{a}}$ actualización. pp. 527. Available from: http://escalera.bio. ucm.es/usuarios/bba/cont/docs/RO_1.pdf

Travé, J., Vachon, M. 1975. François Grandjean. 1882-1975 (Notice biographique et bibliographique). Acarologia, 17(1): 1-19.

Zhang Z.-Q. 2018. Repositories for mite and tick specimens: acronyms and their nomenclature. Syst. Appl. Acarol., 23(12): 2432-2446. doi:10.11158/saa.23.12.12

Zheng Q.F., Liang W.Q., Ren G.R., Yang M.F. 2019. A new species and two newly recorded species of the subgenus Pergalumna (Pergalumna) (Acari, Oribatida, Galumnidae) from China. Zootaxa 4647(1): 407-423. doi:10.11646/zootaxa.4647.1.26 